\title{
Assessment of Thermal Comfort in Operating Rooms Using PMV-PPD Model
}

\author{
A.Khalil $^{\mathrm{a}}$, M.M.Bassuoni ${ }^{\mathrm{b}}$, M.O.Elsamadony ${ }^{\mathrm{c}}$ and M.A.Raslan $^{\mathrm{d}}$ \\ ${ }^{\mathrm{a}-\mathrm{d}}$ Mechanical Power Engineering Department, Faculty of Engineering, Tanta University, Tanta 31521, Egypt \\ ${ }^{\mathrm{d}}$ corresponding author email(mohamed.Atif@f-eng.tanta.edu.eg)
}

\begin{abstract}
Operating rooms (ORs) are the most critical and expensive sector of healthcare facilities. The air conditioning system is designed to provide a well-controlled indoor air quality (IAQ). This design guarantees a perfect infection control and a good thermal comfort of patient and operating staff.
\end{abstract}

This paper aims to analyze and evaluate indoor thermal comfort at different cases to assign the proper inlet air temperature to the OR. The predicted mean vote (PMV) and the predicted percentage dissatisfied (PPD) models in accordance with ISO 7730 were used for this study.

Field measurements were first carried out in an OR at Kafr El-Sheikh educational hospital to get the thermal environment parameters. These parameters are required to determine the thermal comfort indices namely (PMV \& PPD). Four different cases of supplied air temperature $17.5,18.5,19.5$ and $20.5^{\circ} \mathrm{C}$ were studied and compared through 105 measuring points distributed in the operating room. The PMV and PPD indices were computed at each case for three groups of medical staff: surgeons (metabolic rate equal to $\left.120 \mathrm{~W} / \mathrm{m}^{2}\right)$, nurses and surgeon's assistants $(100$ $\left.\mathrm{W} / \mathrm{m}^{2}\right)$, anesthetists $\left(70 \mathrm{~W} / \mathrm{m}^{2}\right)$.

The results revealed that inlet air temperature has a minor effect on the air velocities and airflow patterns inside the $O R$ at the same air change rate. For the current ventilation system, it is difficult to create a very comfortable work conditions for all operating staff at the same time due to their different thermal requirements. It was concluded that a supplied air temperature of $18.5^{\circ} \mathrm{C}$ provides almost comfortable conditions for all surgical staff.

\section{INTRODUCTION}

Hospitals consume the highest energy in the building sector. They contain a combination of various interior spaces, functions and a large number of medical devices which require high space heating, cooling and ventilation loads and continuous 24 hours of operation. Particularly, ORs are the most demanding independent enclosed spaces in hospitals. The OR was classified as a sensitive space that demands a high degree of cleanliness of the environment. According to the ISO 14644-1 standard [1], there are nine class levels of air cleanliness as shown in Table 1. An OR should be at least ISO Class 7 which is an atmospheric environment that contains less than 352,000 particles $0.5 \mathrm{~mm}$ in diameter per cubic meter of air [2]. Therefore, ORs are the most expensive sector of healthcare facilities, accounting for almost $33 \%$ of overall cost. $[3,4]$.

Surgical Site Infections (SSIs) are common surgical issues in hospitals. SSI occurs as pathogenic particles exist in the surgical wound region during surgery. These particles can enter the wound by direct contact or by deposition of airborne particles [5]. In order to minimize the risk of SSI, a systematic but realistic approach must be implemented with understanding that this risk is influenced by characteristics of the patient, operation, personnel, and hospital. Microbial contamination of the surgical site is an essential precursor of SSI [6].

Table 1. Selected airborne particulate cleanliness classes for cleanroom [1]

Classification Maximum concentration limits (particles $/ \mathrm{m}^{3}$ of air) for Numbers ( $N$ particles equal to and larger than the considered sizes shown below

\begin{tabular}{lllllll}
\hline & $0.1 \mu \mathrm{m}$ & $0.2 \mu \mathrm{m}$ & $0.3 \mu \mathrm{m}$ & $0.5 \mu \mathrm{m}$ & $1.0 \mu \mathrm{m}$ & $5.0 \mu \mathrm{m}$ \\
\hline ISO Class 1 & 10 & 2 & & & & \\
ISO Class 2 & 100 & 24 & 10 & 4 & & \\
ISO Class 3 & 1000 & 237 & 102 & 35 & 8 & \\
ISO Class 4 & 10000 & 2370 & 1020 & 352 & 83 & \\
ISO Class 5 & 100000 & 23700 & 10200 & 3520 & 832 & 29 \\
ISO Class 6 & 1000000 & 237000 & 102000 & 35200 & 8320 & 293 \\
ISO Class 7 & & & & 352000 & 83200 & 2930 \\
ISO Class 8 & & & & 3520000 & 832000 & 29300 \\
ISO Class 9 & & & & 35200000 & 8320000 & 293000 \\
\hline
\end{tabular}

Approximately $50 \%$ of doctors works in the ORs, as surgeons or with other duties like anesthesiologists, while about $10 \%$ of the total medical staff work in the OR. The air conditioning system in an operating room is designed to provide the proper indoor air quality (IAQ) including: 1) thermal, visual and acoustical comfort for both the surgical staff and the patient [7], 2) indoor air quality which must be controlled to reduce infection within OR [8]. Therefore, the air in an OR must be aseptic, at a suitable temperature and humidity for the patient and all members of the surgical staff. It should have relatively low velocity in order to avoid drafts and swirls that promote the recirculation of microbes and may disrupt the procedures during an operation.

\section{THERMAL COMFORT AND AIR VENTILATION SYSTEM IN OPERATING ROOMS}

Thermal comfort can be defined as "a condition of mind which expresses satisfaction with the thermal environment" [9, 10]. People's sensation of the thermal environment is evaluated by the International Standard ISO 7730 based on the work of P.O. Fanger[10], who defined the PMV index to predict the thermal sensation of a person. In an operating room a patient is given the highest priority and indoor environment conditions are designed in such a way to ensure patients' safety, health and comfort [11-16], but it is important to remember about operating staff, as their comfort affects indirectly on the quality of work thus lead to a great number of mistakes and decreased work efficiency [16-20]. The proper setting of thermal comfort parameters can provide suitable environment for the personnel. 
The examination of thermal comfort in healthcare facilities has been the subject of several papers. Uncomfortable thermal conditions are not rare in operating rooms. This fact was confirmed by the results of measurements and surveys conducted in different countries [16, 18, 21-23]. A threedimensional CFD modeling in a hospital surgery room was conducted by Ho et al. [24]. They used the resulted airflow velocity and temperature in their PMV calculations. They found that better overall performance can be achieved by placing the grilles of supply air closer to the vertical centerline of the room wall while the location of the exhaust air grilles is somewhat insignificant. The level of thermal comfort and contaminant removal in a hospital operating room was studied by S. H. Ho et al. [25] through a numerical solution for the fluid flow besides assessing the performance of the air conditioning system using Predicted Mean Vote (PMV) model. It was found that the airflow patterns and the location of air supply grilles have a significant influence on the thermal comfort of occupants. A. Pourshaghaghy and M. Omidvari [17] studied the level of thermal comfort and performance of air conditioning system in a hospital located in Kermanshah city in the west of Iran in winter and summer using the PMV-PPD model based on the experimental measurements were performed. They found that the poorest thermal conditions in winter occurred in morning shift. In summer, the poorest thermal conditions occurred in noon shift (in hours between 14 and $16 \mathrm{AM})$. The thermal conditions and thermal sensation of medical staff working at Polish hospitals and operating rooms were evaluated based on field measurements which were carried out by Piotr Us'cinowicz et al. [22] in 37 ORs in 7 Warsaw hospitals. They found that creation of working conditions that would be comfortable to operating staff is a significant problem. Waqas Khalid et al. [26] examined the indoor thermal comfort of patients and visitors in patient rooms in three different hospitals in Malaysia and compare it with international and local standards. They indicated that more than $86 \%$ of patients as well as visitors were thermally acceptable within the operative temperature range of $22.0-$ $28.0{ }^{\circ} \mathrm{C}$. They also studied the relationship between indoor comfort conditions and outdoor temperature and found that a change of $4.0{ }^{\circ} \mathrm{C}$ in running mean outdoor temperature leads to a $1.3{ }^{\circ} \mathrm{C}$ and $2.2{ }^{\circ} \mathrm{C}$ change in indoor comfort temperature for in-patients and visitors, respectively, which can save energy in the studied hospitals.

On the other hand, the goal of the air distribution inside an OR is to protect the patient and staff from cross-infection while maintaining occupant comfort without affecting the facilitation of surgical tasks. However, a source of contamination bypasses HEPA installations in every OR, this source being the surgical staff themselves and the particles stirred up by their movement (Cook and Int-Hout [27]. Therefore, air motion control must be used to maximize air asepsis. Memarzadeh and Manning [28] studied different ORs with different ventilation systems. Their results show that ventilation systems with laminar flow are the best choice. Khalil et al. [29] used experimental measurements and mathematical modelling techniques to determine the thermal and relative humidity characteristics in an OR. They examined different variations of supply and exhaust air locations and found that the optimum way to sterilize the operating area was using unidirectional air supply. The ventilation system defines not only the air flow in the operating room, but also the thermal conditions. In addition to prevent SSI, the technical HVAC standards state that thermal comfort must be achieved for the patient and all members of the surgical staff in the operating room.

R. Van Gaever et al. [21] indicated the conflict between the thermal comfort standard ISO 7730 [30] and the environmental parameters defined by the technical HVAC standards as they presented the environmental parameters of five different technical HVAC standards and guidelines. It was also found that the current HVAC standards and ventilation systems failed to provide a comfortable thermal environment for all members of surgical staff in the operating room.

The primary goal of this study is to examine and evaluate the thermal conditions inside the OR and estimate the optimal inlet air temperature which achieve a high level of thermal comfort for all surgical staff. Thermal conditions of the OR are evaluated based on PMV and PPD indices.

\section{PREDICTED MEAN VOTE (PMV) AND PREDICTED PERCENTAGE DISSATISFIED (PPD)}

According to [21, 30-32] in case of surgical staff in ORs i.e. healthy adults whose working specificity limit their adaptation ability the PMV index is sufficient to obtain accurate results. Effectiveness of PMV model for evaluating thermal conditions on surgical wards was also confirmed in the studies $[8,17]$. In those studies, the variance between survey results and PMV measurements, conducted simultaneously with survey, did not exceed $5 \%$. Based on the above-mentioned information, the PMV index was chosen to provide optimum levels of accuracy for evaluating OR thermal conditions.

The PMV is an index which predicts the mean value of the votes of a large group of occupants on the 7-point thermal sensation scale shown in Table 2 based on the heat balance of the human body. The PPD on the other hand, predicts the percentage of occupants who are unsatisfied with the thermal conditions inside the space they are in.

Table 2. Thermal sensation scale used by Fanger.[32]

\begin{tabular}{cccccccc}
\hline PMV & -3 & -2 & -1 & 0 & +1 & +2 & +3 \\
\hline $\begin{array}{c}\text { Thermal } \\
\text { sensatio } \\
\mathbf{n}\end{array}$ & Col & Coo & Slightl & Neutra & Slightl & War & Ho \\
& 1 & y cool & 1 & y warm & m & t \\
\hline
\end{tabular}

An environment is considered as very comfortable when PMV varies between -0.5 and +0.5 . It is considered as comfortable between 1.0 and +1.0 . These values lead to a PPD of $10 \%$ and $27 \%$ for $0.5 \mathrm{PMV}+0.5$ and $1.0 \mathrm{PMV}+1.0$, respectively. When PMV is zero, that is to say for the perfect case, the PPD is $5 \%$.

The ISO 7730 standard [30] gives the following equations to calculate PMV:

$$
\begin{aligned}
& P M V=[0.303 * \exp (-0.036 * M)+0.028] * \\
& \left\{(M-W)-3.05 * 10^{-3} *[5733-6.99 *\right. \\
& \left.(M-W)-P_{a}\right]-0.42 *[(M-W)-58.15]- \\
& 1.7 * 10^{-5} * M *\left(5867-P_{a}\right)-0.0014 * M *
\end{aligned}
$$




$$
\begin{aligned}
& \left(34-t_{a}\right)-3.96 * 10^{-8} * f_{c l} *\left[\left(t_{c l}+273\right)^{4}-\right. \\
& \left.\left.\left(\bar{t}_{r}+273\right)^{4}\right]-f_{c l} * h_{c} *\left(t_{c l}-t_{a}\right)\right\} \\
& t_{c l}=35.7-0.028 *(M-W)-I_{c l} *\{3.96 * \\
& 10^{-8} * f_{c l} *\left[\left(t_{c l}+273\right)^{4}-\left(\bar{t}_{r}+273\right)^{4}\right]+f_{c l} * \\
& \left.h_{c} *\left(t_{c l}-t_{a}\right)\right\}
\end{aligned}
$$$$
h_{c}=\left\{\begin{array}{cc}
2.38 *\left|t_{c l}-t_{a}\right|^{0.25} \\
\text { for } & 2.38 *\left|t_{c l}-t_{a}\right|^{0.25}>12.1 * \sqrt{v_{a r}} \\
& 12.1 * \sqrt{v_{a r}} \\
\text { for } & 2.38 *\left|t_{c l}-t_{a}\right|^{0.25}<12.1 * \sqrt{v_{a r}}
\end{array}\right.
$$$$
f_{c l}=\left\{\begin{array}{c}
1.00+1.290 * I_{c l} \\
\text { for } \quad I_{c l} \leq 0.078 \mathrm{~m}^{2} \cdot \frac{K}{W} \\
1.05+0.645 * I_{c l} \\
\text { for } \quad I_{c l}>0.078 \mathrm{~m}^{2} \cdot K / W
\end{array}\right.
$$

Where, $\mathrm{M}$ is the metabolic rate of a human body $\left(\mathrm{W} / \mathrm{m}^{2}\right), \mathrm{W}$ is the effective mechanical power done by a person $\left(\mathrm{W} / \mathrm{m}^{2}\right), \mathrm{I}_{\mathrm{cl}}$ is the clothing insulation $\left(\mathrm{m}^{2} . \mathrm{K} / \mathrm{W}\right), f_{\mathrm{cl}}$ is the clothing surface area factor, $\mathrm{t}_{\mathrm{a}}$ is the indoor air temperature $\left({ }^{\circ} \mathrm{C}\right), \mathrm{t}_{\mathrm{r}}$ is the mean radiant temperature $\left({ }^{\circ} \mathrm{C}\right), v_{a r}$ is the relative air velocity $(\mathrm{m} / \mathrm{s}), \mathrm{P}_{\mathrm{a}}$ is the water vapor partial pressure $(\mathrm{Pa}), \mathrm{h}_{\mathrm{c}}$ is the convective heat transfer coefficient $\left(\mathrm{W} / \mathrm{m}^{2} . \mathrm{K}\right)$ and $t_{\mathrm{cl}}$ is the clothing surface temperature $\left({ }^{\circ} \mathrm{C}\right)$.

The predicted percentage dissatisfied (PPD) is a function of PMV and is given by:

$$
\begin{aligned}
& P P D=100-95 * \exp \left(-0.03353 * P M V^{4}-\right. \\
& \left.0.2179 * P M V^{2}\right)
\end{aligned}
$$

Based on the OR environment and personnel characteristics, our basic assumptions were as follows:

- Air temperature, air velocity and relative humidity were measured as mentioned above.

- Heat transfer through radiation issue is not completely specified in any standard, although recommendations that mean radiant temperature $t_{r}$ should be similar to indoor air temperature [22, 33].

- $\quad P a$ the water vapor partial pressure using relatively relative humidity. It was derived with $\mathrm{t}_{\mathrm{a}}$ and $\varphi$ [34].

- The thermal insulation $\mathrm{I}_{\mathrm{cl}}$ of clothing was assumed as equal to $\left(1\right.$ clo $\left.=0.155 \mathrm{~m}^{2} \mathrm{~K} / \mathrm{W}\right)$ for surgical underwear and standard performance gown $[35,36]$.

- With regard to thermal requirements, medical staff can be divided into three basic groups [18]: surgeons, nurses and surgeon's assistants, anesthetists. Each group works under a different physical and mental load [16, 18, 21]. Therefore, PMV indices were calculated for three groups of medical staff: surgeons (metabolic rate equal to $120 \mathrm{~W} / \mathrm{m}^{2}$ ), nurses and surgeon's assistants $\left(100 \mathrm{~W} / \mathrm{m}^{2}\right)$, anesthetists $(70$ $\mathrm{W} / \mathrm{m}^{2}$ ) [30, 37].

\section{MATERIAL AND METHODS}

\section{A. Description of operating room}

In the present work, Kafr El-Sheikh educational hospital at the university of Kafr El-Sheikh, Egypt was chosen for performing the presented work. There are eight ORs, OR-7 on the second floor is designed to serve ear, nose and throat (ENT) surgeries where the measuring data were collected.

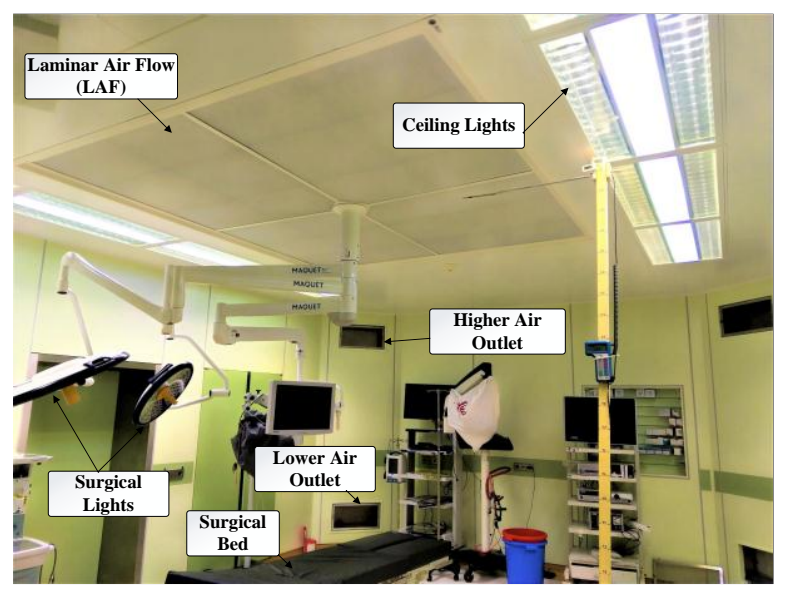

Fig. 1. The interior arrangement of the operating room.

Fig. 1 shows the interior arrangement of the operating room. It is $7.50 \mathrm{~m}(\mathrm{~L}) \times 5.36 \mathrm{~m}(\mathrm{~W}) \times 3.00 \mathrm{~m}(\mathrm{H})$ and all walls are well insulated. The neighboring walls to OR are conditioned. The supplied air flows downwards through a central ceiling supply plenum with multiperforated diffusers with a total area of $(2.2 \mathrm{~m} \mathrm{x} 2.8 \mathrm{~m})$ and equipped with high-efficiency particulate air filters (HEPA). A single totally fresh air handling unit (FAHU) provides the ventilation air for the OR at constant speed.

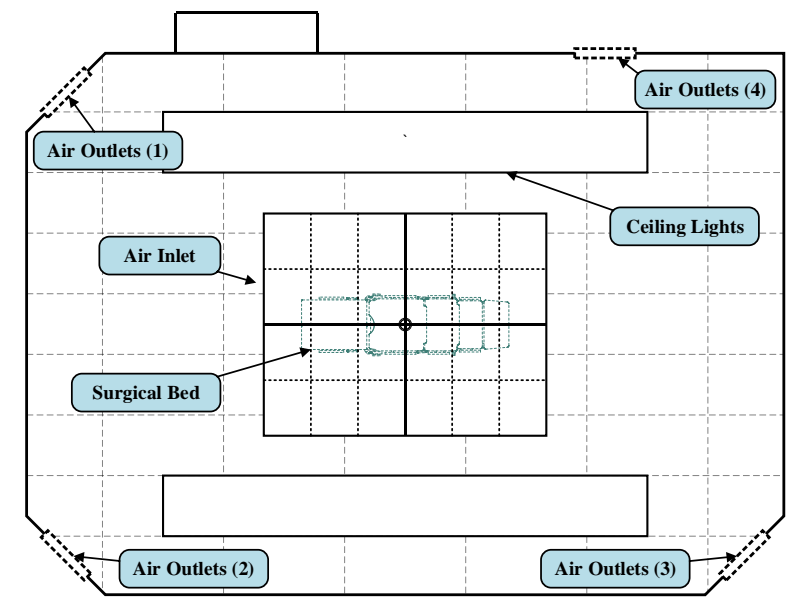

Fig. 2. The plane of the operating room.

Two exhaust grille groups are installed, four grille outlets $0.58 \mathrm{~m} \times 0.28 \mathrm{~m}$ are installed near the floor which absorb $2 / 3$ of the air and four grille outlets $0.58 \mathrm{~m} \times 0.28$ $\mathrm{m}$ are installed near the ceiling which absorb $1 / 3$ of the air, as shown in Fig. 2. This system provides a continuous, 
unidirectional flow of clean air at a rate of $30 \mathrm{ACH}$ to protect the operating zone, instrument table, patient and surgical staff from pathogenic particle.

\section{B. Measuring Instruments}

VelociCalc plus air velocity meter $8386 \mathrm{~A}$ was used for collecting data. It was used to measure temperature, relative humidity and air velocity with sensor accuracy of $0.3{ }^{\circ} \mathrm{C}, \quad 3 \%$ and $0.015 \mathrm{~m} / \mathrm{s}$ respectively. Digital temperature panel meter TPM-30 was also used to measure the temperature of air at two different points (The same point which the VelociCalc measures and another point at the air inlet along the same vertical axis). The technical data of instruments illustrated in Table 3.

Table 3. Technical data of instruments used for the experimental measurements.

\begin{tabular}{|c|c|c|c|c|}
\hline $\begin{array}{l}\text { Measurement } \\
\text { instrument }\end{array}$ & Parameter & Range & Resolution & Accuracy \\
\hline $\begin{array}{l}\text { VelociCalc } \\
\text { 8386A }\end{array}$ & $\begin{array}{l}\text { Temperature } \\
\text { Relative } \\
\text { humidity } \\
\text { Air Velocity }\end{array}$ & $\begin{array}{l}-10 \sim \\
60{ }^{\circ} \mathrm{C} \\
0 \sim \\
95 \% \\
\mathrm{RH} \\
0 \sim 50 \\
\mathrm{~m} / \mathrm{s}\end{array}$ & $\begin{array}{l}0.1^{\circ} \mathrm{C} \\
0.1 \% \mathrm{RH} \\
0.01 \mathrm{~m} / \mathrm{s}\end{array}$ & $\begin{array}{l} \pm 0.3^{\circ} \mathrm{C} \\
\pm 3 \% R H \\
\pm 0.015 \mathrm{~m} \\
/ \mathrm{s}\end{array}$ \\
\hline TPM-30 & Temperature & $\begin{array}{l}-50 \sim \\
+70 \\
{ }^{\circ} \mathrm{C}\end{array}$ & $\begin{array}{l}>-20^{\circ} \mathrm{C}, \\
0.1{ }^{\circ} \mathrm{C} \\
\leq-20{ }^{\circ} \mathrm{C}, 1 \\
{ }^{\circ} \mathrm{C}\end{array}$ & $\pm 1^{\circ} \mathrm{C}$ \\
\hline
\end{tabular}

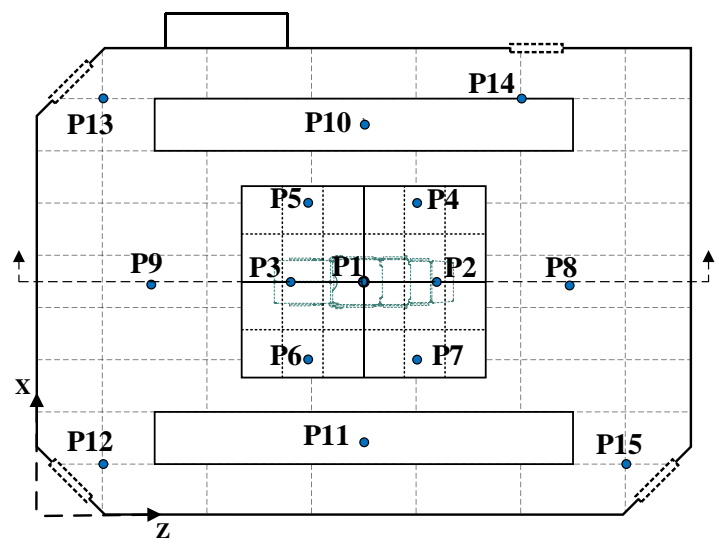

(a)

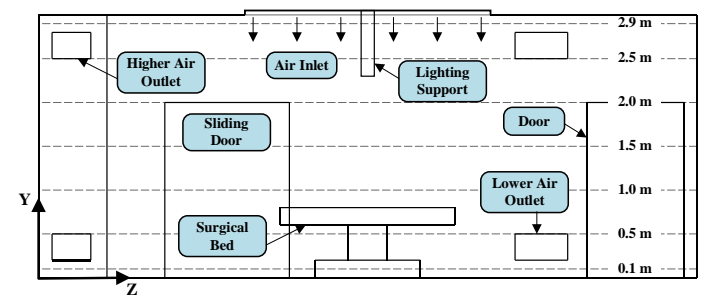

(b)

Fig. 3. (a) Measuring points on each horizontal plane in the OR and (b) Section plane of the OR indicates seven horizontal planes.

\section{Airflow field measurements}

Thermal conditions were measured in the OR at seven horizontal planes. These planes are at height of $(0.1 \mathrm{~m}$, $0.5 \mathrm{~m}, 1 \mathrm{~m}, 1.5 \mathrm{~m}, 2 \mathrm{~m}, 2.5 \mathrm{~m}$ and $2.9 \mathrm{~m}$ ) from the above floor level as shown in Fig. 3(b). Each horizontal plane contains 15 measuring points located in the way presented in Fig. 3(a). Measuring points (1-7) are located within the operating zone and other points (8-15) are situated outside the operating zone. The purpose of field measurements is to obtain the values of parameters required to calculate PMV and PPD indices which represent the thermal comfort inside the OR. The field measurements were performed at August. The data collection was conducted from 12:00 $\mathrm{pm}$ to 4:00 $\mathrm{pm}$. These data were recorded every 2 minutes interval during this period. The instruments arrangement is shown in Fig. 4. The hot wire anemometer was attached to a stand which moves horizontally from $\mathrm{P} 1$ to $\mathrm{P} 15$. At each point, the probe moves vertically to acquire parameters at each height. Average values of the thermal condition parameters were specified for each point the following thermal environment parameters: air temperature $\left(\mathrm{t}_{\mathrm{a}}\right)$, air velocity $\left(v_{\mathrm{a}}\right)$ and relative humidity of air $(\mathrm{RH})$. The measurements were performed at August where the heat gain is the biggest issue. For each measuring point the following conditions were assumed: measurements were allowed only when surgical procedures were over, during measurements general lighting were switched on, operating room doors were kept closed and ventilation and air-conditioning system was on.

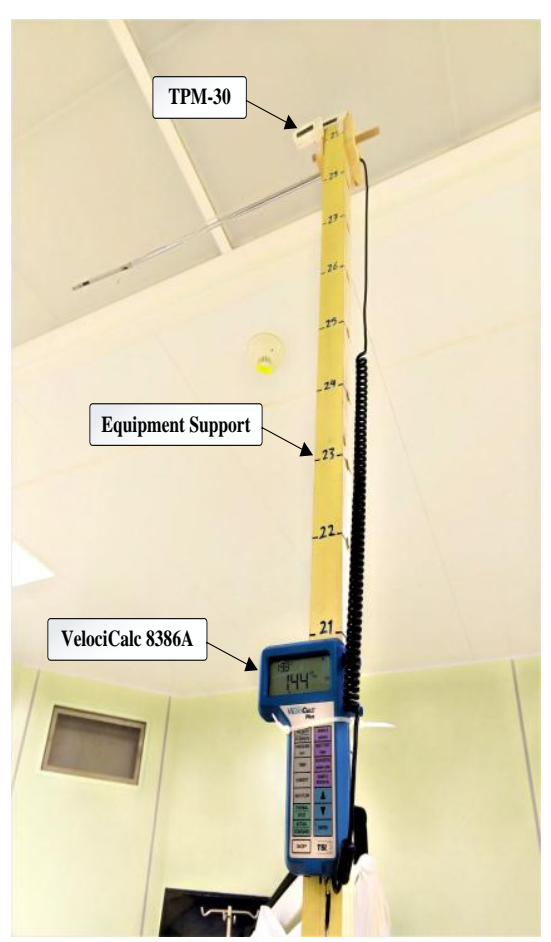

Fig. 4. Setup of measuring instruments. 


\section{RESULTS AND DISCUSSION OF MEASUREMENTS}

\section{A. Environmental parameters}

Studied cases of OR are represented in Table 4. For each case, both of inlet air temperature and velocity were measured at 24 measuring points at the supply ceiling diffusers. Then, the values of each case were averaged. The supplied air is certainly a bit colder than the average room temperature with a value less than $1 \mathrm{oC}$, which means that it has a negative buoyancy and will gain speed and contract as it drops into the room. The downward direction of the supply airflow and supply to room air temperature difference required for meeting the space cooling load produces a mixed convection condition that is sensitive to the Archimedes number. Archimedes number can be described as the ratio of the buoyancy force to the momentum force. Here in our case, since the inlet air velocity is constrained by the air change rate and the velocity is high enough to drive the supply air jet by momentum more than buoyancy. As indicated in Table 4, the buoyancy force has a quite effect on the supplied air velocity as the buoyancy force is a function of the supply air to room air temperature difference. Therefore, as the temperature difference increases the acceleration of the supply air jet increases. Taking into
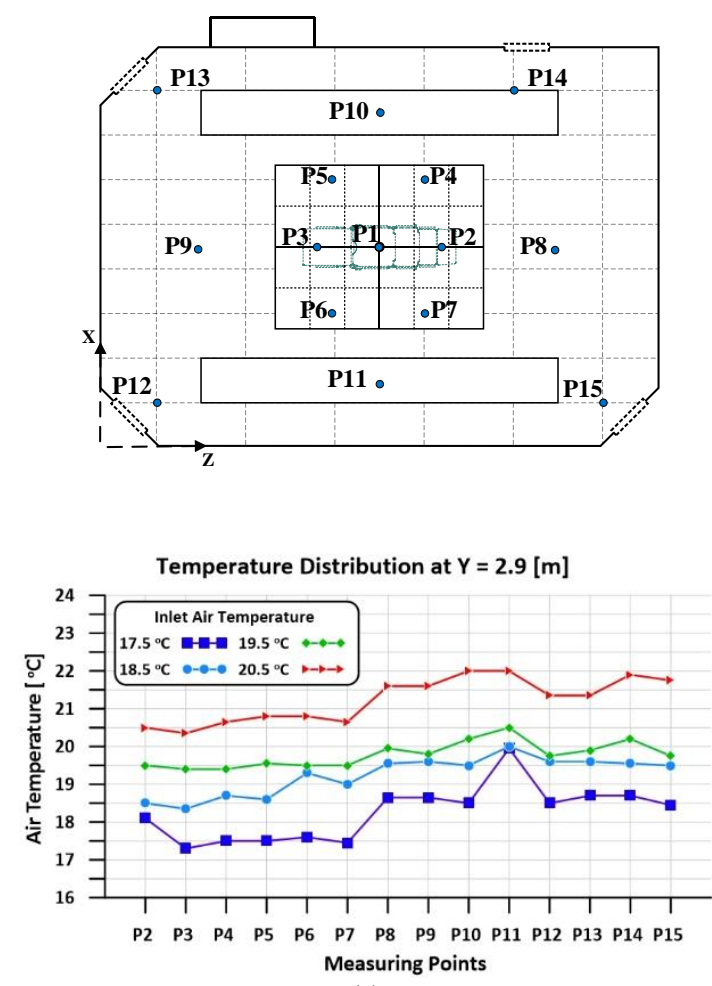

(a) consideration that there are no thermal plumes sources against the downward airflow during measurements.

\begin{tabular}{cccc} 
Tabes & $\begin{array}{c}\text { Average } \\
\text { Inlet Air } \\
\text { Temperature } \\
\left({ }^{\mathbf{C}} \mathbf{C}\right)\end{array}$ & $\begin{array}{c}\text { Average } \\
\text { Room Air } \\
\text { Temperature } \\
\left({ }^{\mathbf{0}} \mathbf{C}\right)\end{array}$ & $\begin{array}{c}\text { Average } \\
\text { Inlet air } \\
\text { Velocity } \\
(\mathbf{m} / \mathbf{s})\end{array}$ \\
\hline Case 1 & 17.5 & 18 & 0.365 \\
\hline Case 2 & 18.5 & 19.1 & 0.36 \\
\hline Case 3 & 19.5 & 19.8 & 0.35 \\
\hline Case 4 & 20.5 & 20.7 & 0.318 \\
\hline
\end{tabular}

Fig. 5 and Fig. 6 present the air temperature and velocity measurement results through 105 measuring points in the OR distributed on seven planes $0.1,0.5,1,1.5,2,2.5$ and 2.9 m. Every plane contains 15 points distributed on $y$-axis sequentially. Each graph compares four cases of inlet air temperature $17.5,18.5,19.5$ and $20.5^{\circ} \mathrm{C}$ at specified plane. Point P1 has no value at levels of 2.9, 2.5, 0.5 and $0.1 \mathrm{~m}$ due to existence of the surgical light support and the base of the surgical bed, respectively. Fig. 5 shows that the higher air inlet temperature the higher room air temperature. Points P10, P11 and P14 have the highest temperatures near the ceiling due to the heat flux results from the ceiling lights.

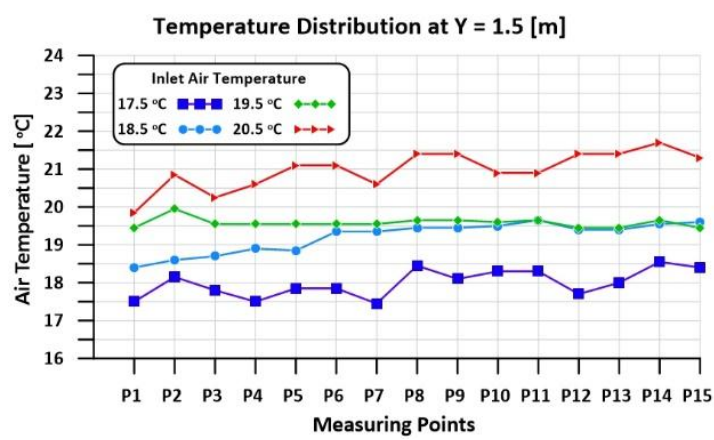

(d)

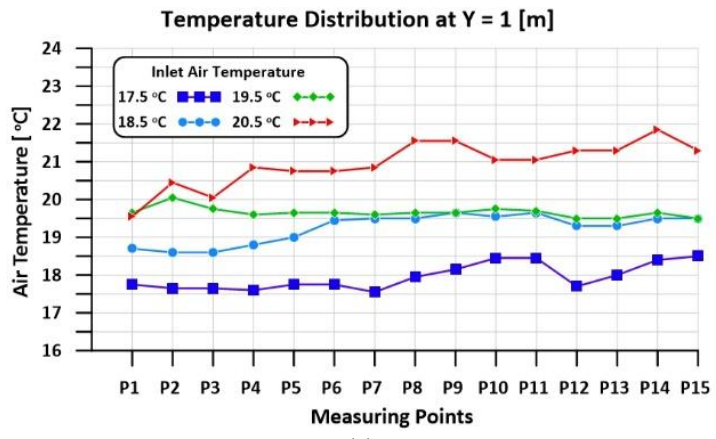

(e) 


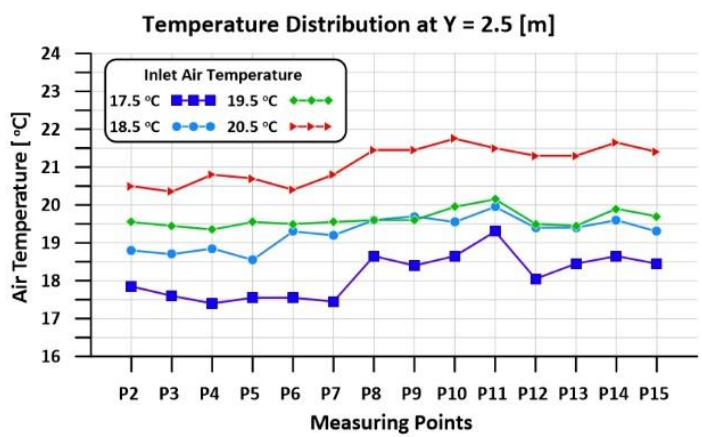

(b)

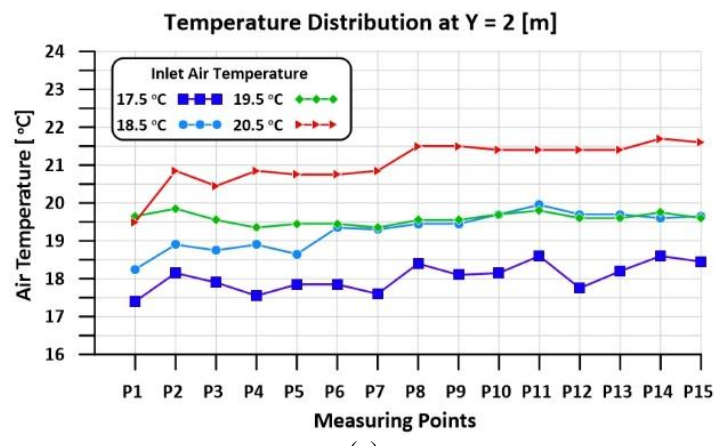

(c)

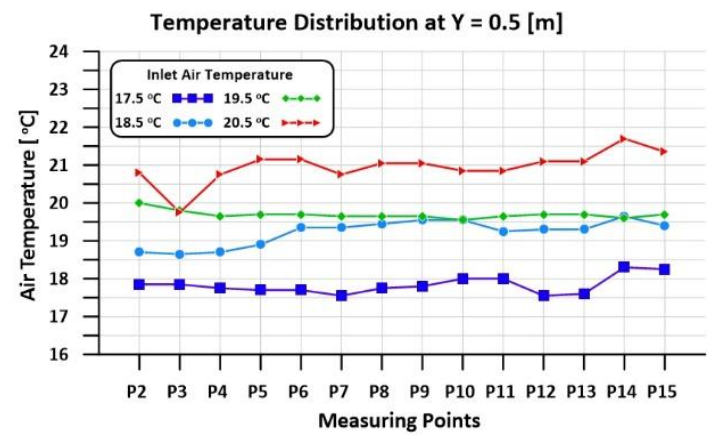

(f)

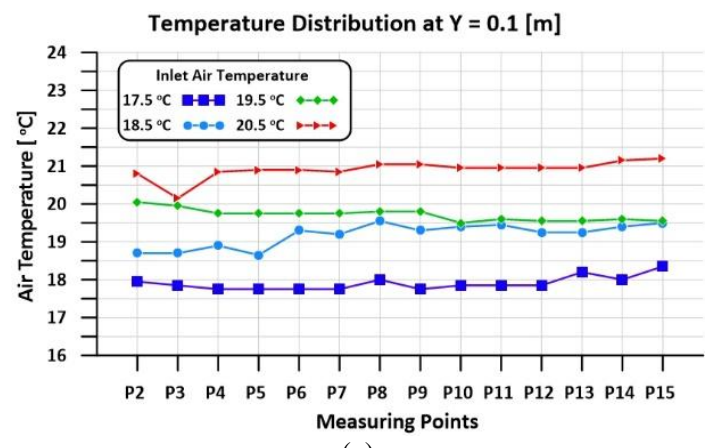

(g)

Fig. 5 Temperature distribution at different inlet air temperature at different elevations: (a) $y=2.9 \mathrm{~m},(\mathrm{~b}) \mathrm{y}=2.5 \mathrm{~m},(\mathrm{c}) \mathrm{y}=2 \mathrm{~m},(\mathrm{~d}) \mathrm{y}=1.5 \mathrm{~m},(\mathrm{e}) \mathrm{y}=1 \mathrm{~m}$, (f) $\mathrm{y}=0.5 \mathrm{~m}$ and $(\mathrm{g}) \mathrm{y}=0.1 \mathrm{~m}$.

According to Fig. 6 the supplied air temperature in all cases enters the OR with a velocity lower than $0.4 \mathrm{~m} / \mathrm{s}$, as the airflow goes down the air velocity increases and reaches its maximum value at level of $2 \mathrm{~m}$ from the floor. While the airflow draws down near the operating table, a reverse flow is produced over the operating table due to its bluff-body shape resulting in a detraction of downstream airflow velocity then the velocity continues decreasing till the airflow reaches the floor. P8, P9, P10 and $\mathrm{P} 11$ around the clean surgical area recorded the lowest values of air velocity almost zero which indicating the presence of stagnant or dead zone in the surrounding of operating area extends from ceiling till $1 \mathrm{~m}$ above the floor

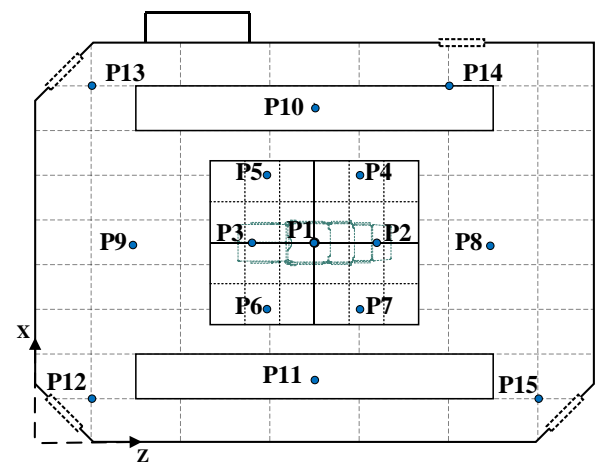

level. Below $1 \mathrm{~m}$ level as indicated in Fig. 6(e) and Fig. 6 (f), the measured airflow velocity showed a relative increase due to the extraction effect of exhaust grilles. Stagnant zone experiences inadequate local ventilation rates, subsequent accumulation of contaminates, and degrading of thermal comfort. However, this does not prevent the appearance of dead zones. Proper selection and position of air return grilles would improve the room airflow pattern and result in more consistent airflow distribution and reduce such risk. The graphs in Fig. 6 indicate that changes in inlet air temperatures have minor effect on the air velocities and airflow patterns inside the OR.

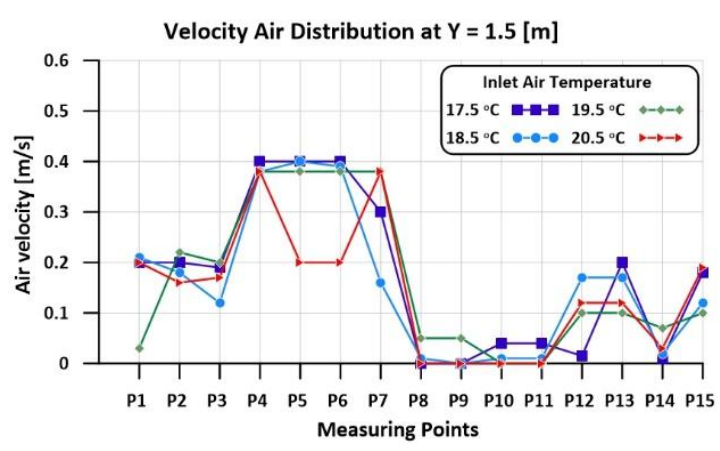

(d) 


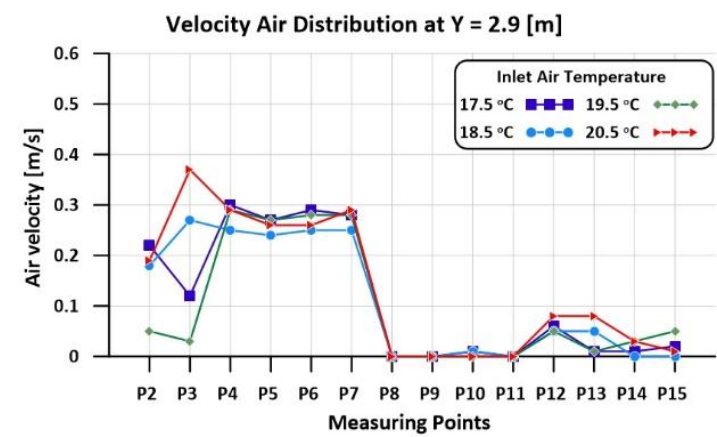

(a)

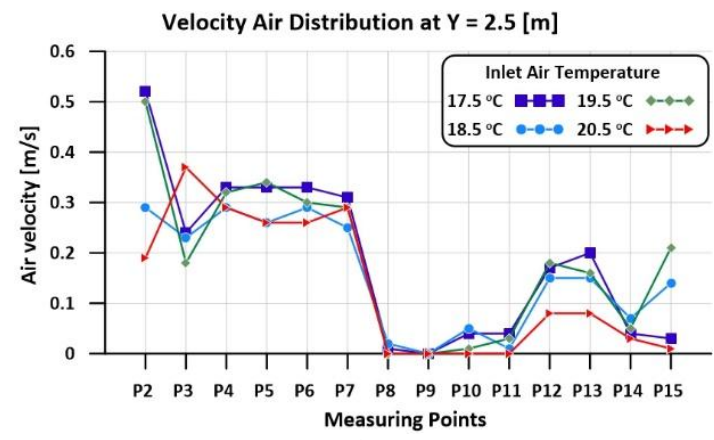

(b)

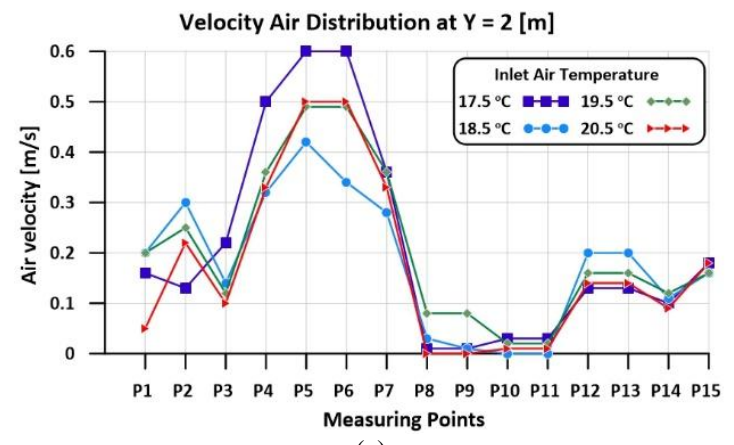

(c)

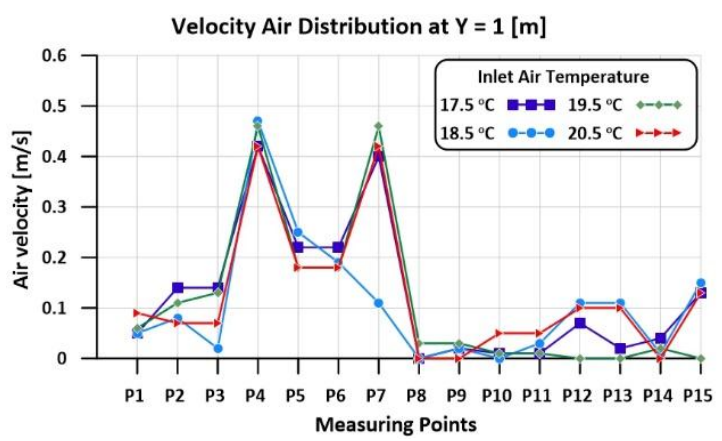

(e)

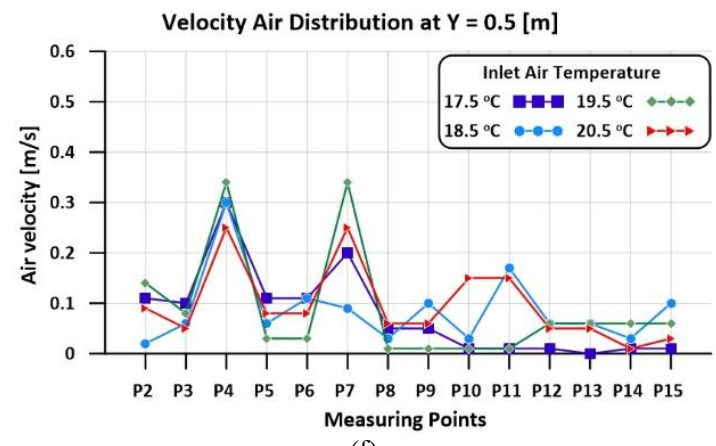

(f)

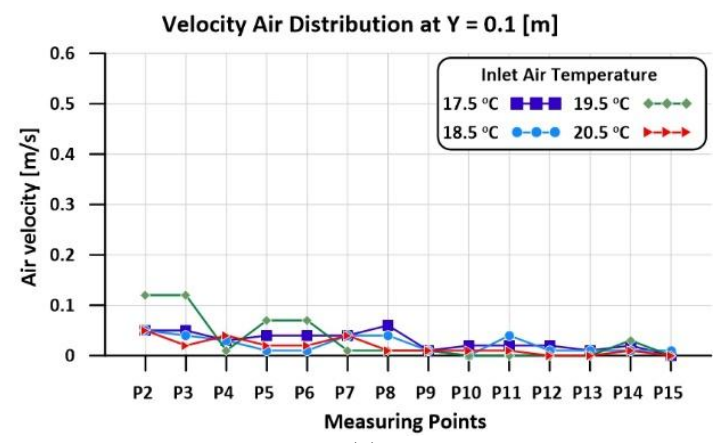

(g)

Fig. 6 Velocity distribution at different inlet air temperature at different elevations: (a) $y=2.9 m$, (b) $y=2.5 m$, (c) $y=2 m$, (d) $y=1.5 m$, (e) $y=1 \mathrm{~m}$, (f) $y=0.5 \mathrm{~m}$ and $(\mathrm{g}) \mathrm{y}=0.1 \mathrm{~m}$.

Fig. 7, Fig. 8, Fig. 9 and Fig. 10 present the distribution of the interesting variables air temperature and air velocity respectively by displaying respective

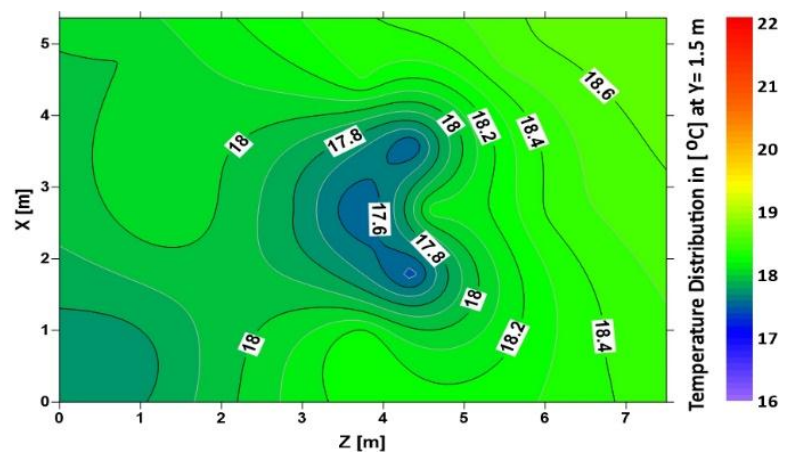

(a) interpolated filled color on orthogonal slice planes using Surfer software through field measurement data at levels of interest at $\mathrm{y}=1.5$ and $1 \mathrm{~m}$ from the floor.

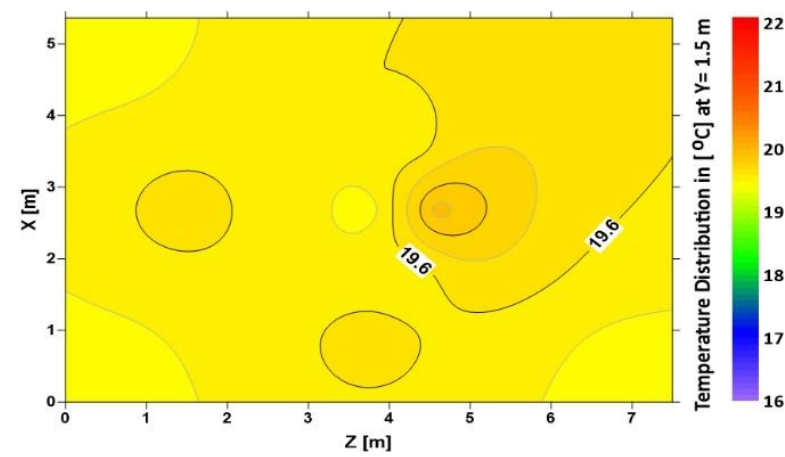

(c) 


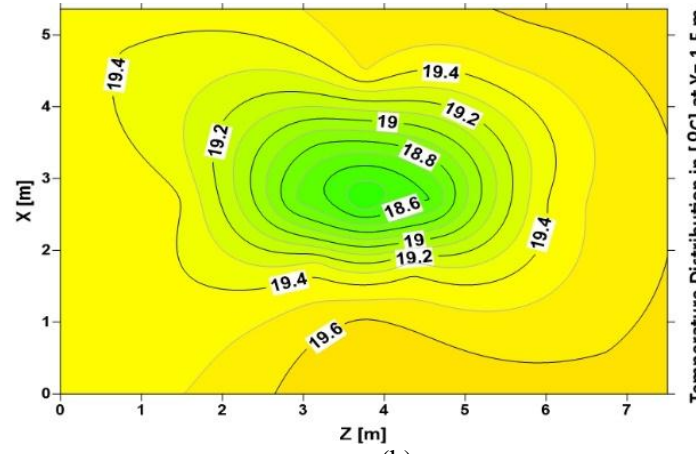

(b)

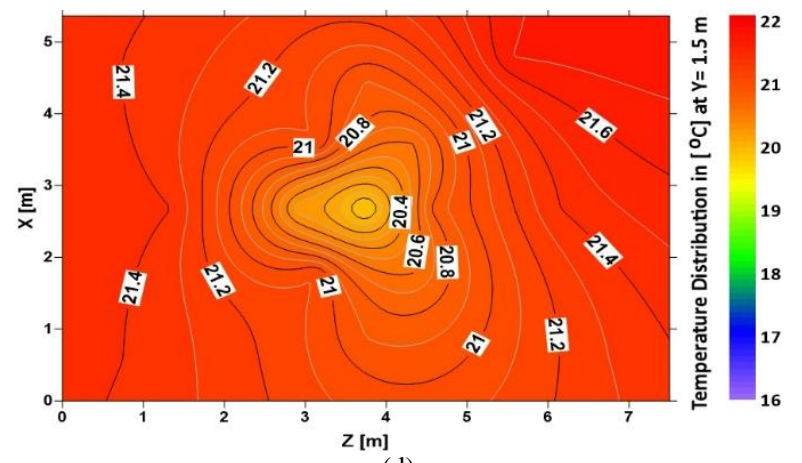

(d)

Fig. 7 Temperature contours in XZ-plane at $y=1.5 \mathrm{~m}$ at (a) $t_{i n}=17.5^{\circ} \mathrm{C}$, (b) $t_{i n}=18.5^{\circ} \mathrm{C}$, (c) $t_{i n}=19.5^{\circ} \mathrm{C}$ and $(d) t_{i n}=20.5^{\circ} \mathrm{C}$.

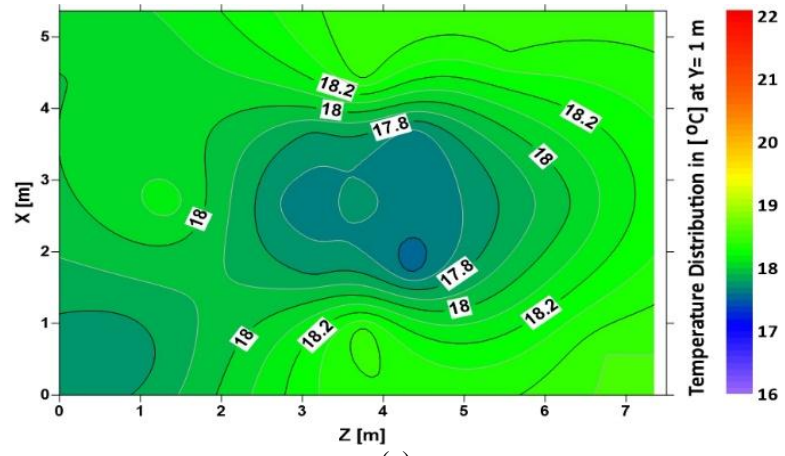

(a)

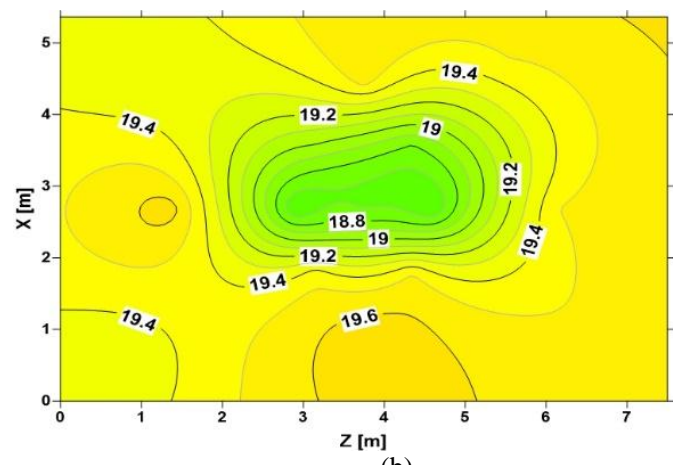

(b)

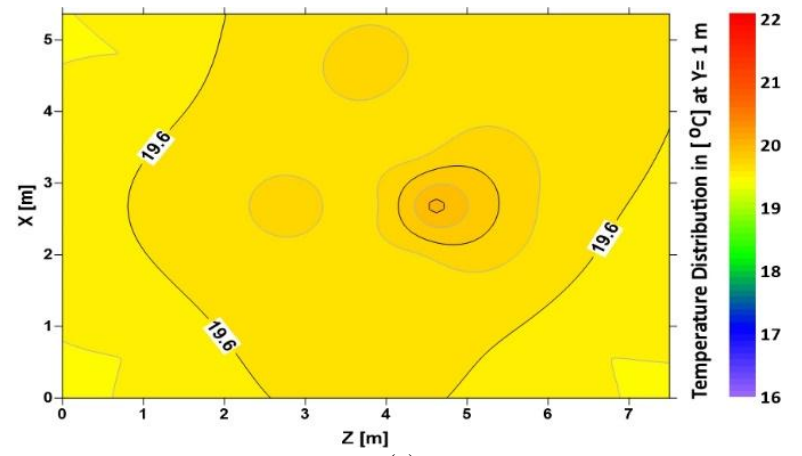

(c)

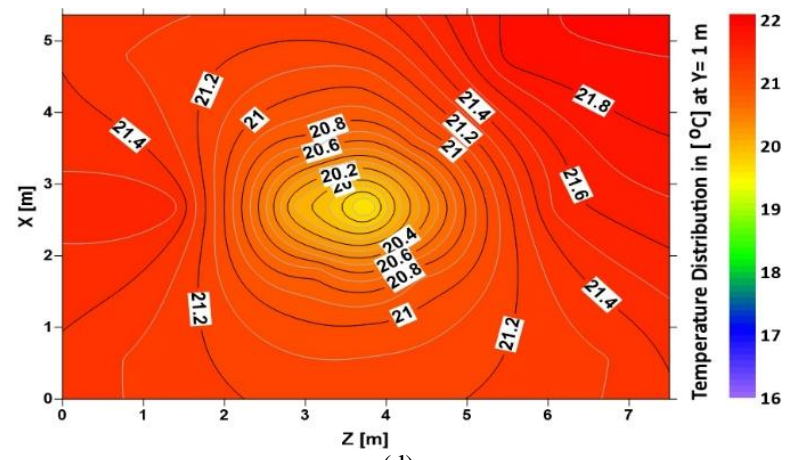

(d)

Fig. 8 Temperature contours in XZ-plane at $y=1 \mathrm{~m}$ at (a) $\mathrm{t}_{\mathrm{in}}=17.5^{\circ} \mathrm{C}$, (b) $\mathrm{t}_{\mathrm{in}}=18.5^{\circ} \mathrm{C}$, (c) $\mathrm{t}_{\mathrm{in}}=19.5^{\circ} \mathrm{C}$ and $(\mathrm{d}) \mathrm{t}_{\mathrm{in}}=20.5^{\circ} \mathrm{C}$.

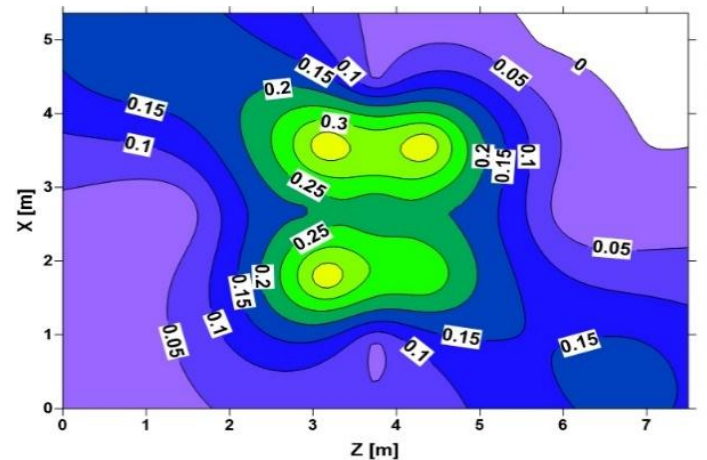

(a)
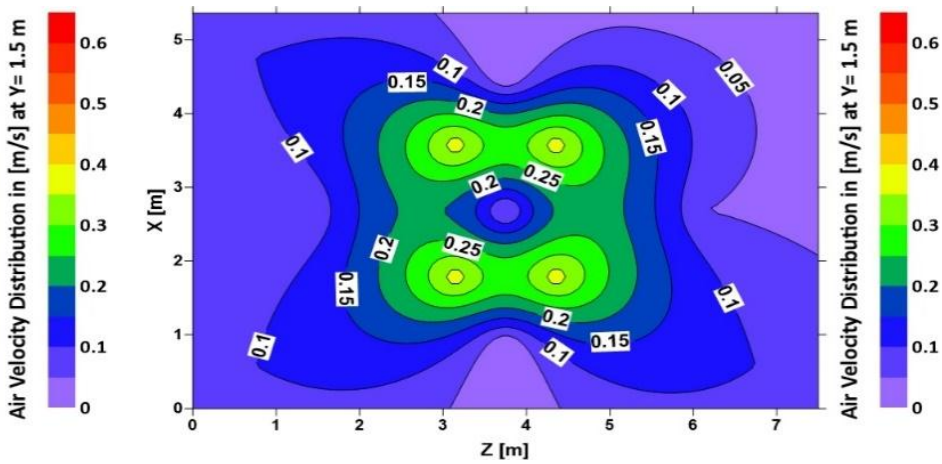

(c) 


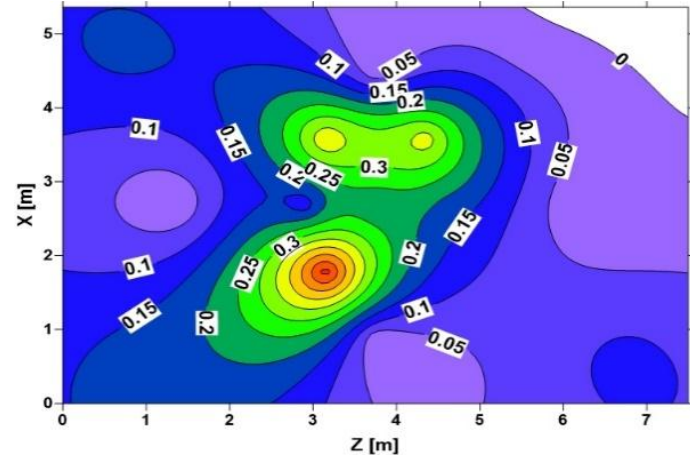

(b)
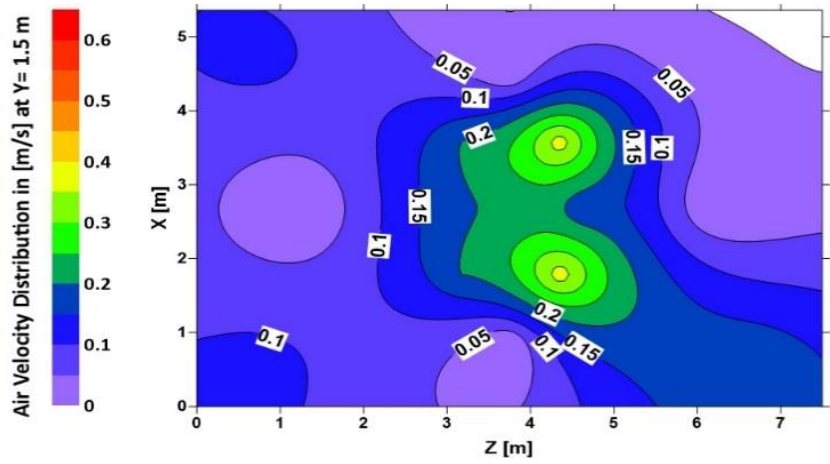

(d)

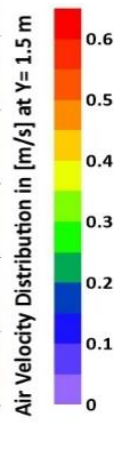

Fig. 9 Air velocity contours in XZ-plane at $y=1.5 \mathrm{~m}$ at (a) $\mathrm{t}_{\mathrm{in}}=17.5^{\circ} \mathrm{C}$, (b) $\mathrm{t}_{\mathrm{in}}=18.5^{\circ} \mathrm{C}$, (c) $\mathrm{t}_{\mathrm{in}}=19.5^{\circ} \mathrm{C}$ and (d) $\mathrm{t}_{\mathrm{in}}=20.5^{\circ} \mathrm{C}$.
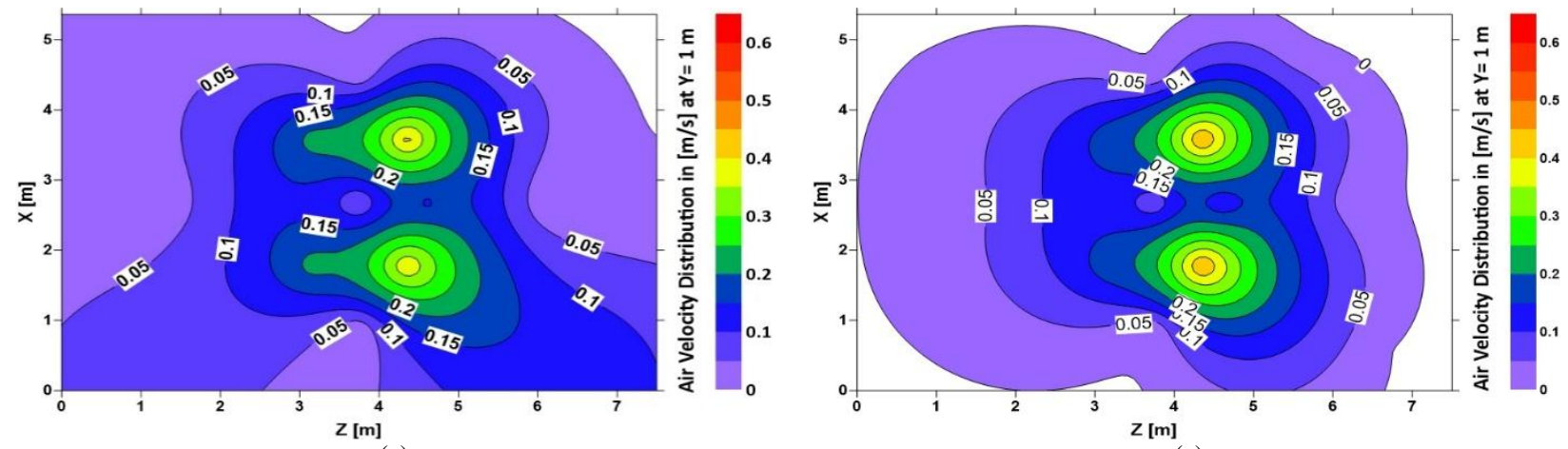

(a)

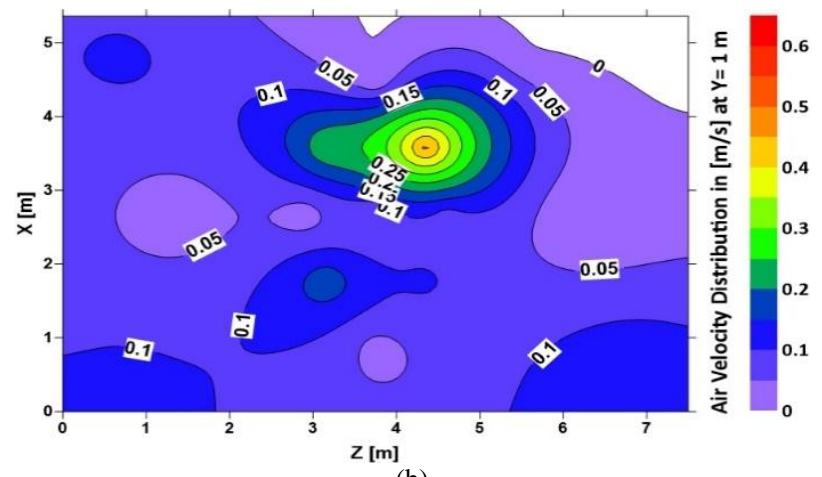

(b)

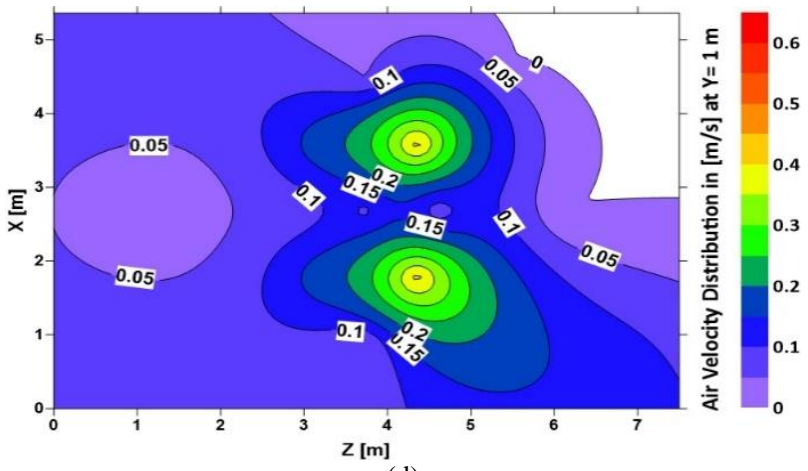

(d)

Fig. 10 Air velocity contours in XZ-plane at $y=1 \mathrm{~m}$ at (a) $\mathrm{t}_{\mathrm{in}}=17.5^{\circ} \mathrm{C}$, (b) $\mathrm{t}_{\mathrm{in}}=18.5^{\circ} \mathrm{C}$, (c) $\mathrm{t}_{\mathrm{in}}=19.5^{\circ} \mathrm{C}$ and (d) $\mathrm{t}_{\mathrm{in}}=20.5^{\circ} \mathrm{C}$.

\section{B. Thermal comfort in the operating room}

In this study, the primary goal is to improve thermal comfort inside the operating room by identifying the proper inlet air temperature which achieve the thermal comfort for all operating staff at the same time. Four cases of inlet air temperature were considered, which are indicated above in Table 4. PMV and PPD indices were proposed to evaluate the thermal comfort of the medical staff of the OR. Thermal sensations experienced by operating staff were described with the PMV index [32] according to requirements of ISO 7730 standard [30]. Based on the measured and calculated environmental and human factors data, the PMV and PPD indices were determined and results of the calculations are presented in table 5 and plotted in Fig. 11 and Fig. 12.

Fig. 11 shows plots of PMV values for each case mentioned in Table 4 at two levels of interest $y=1 \mathrm{~m}$ and $1.5 \mathrm{~m}$ from the floor. The averaged-PMV values were calculated at each level based on the magnitudes of air temperature, airflow velocity, mean radiant temperature and relative humidity for seven points located in the surgical clean area underneath the laminar airflow diffusers, together with occupants' metabolic rate and clothing thermal resistance. Both of Fig. 11(a) and Fig. 11(b) contains three PMV graphs, one for each medical staff group in which a comparison of PMV values at different supplied air temperature is showed. 
Table 5. PMV and PPD results.

\begin{tabular}{|c|c|c|c|c|c|}
\hline $\begin{array}{l}\text { Medical staff } \\
\text { Group }\end{array}$ & Inlet air temperature & Elevation & PMV & Thermal sensation & PPD \\
\hline \multirow[t]{8}{*}{ Surgeons } & \multirow{2}{*}{$17.5^{\circ} \mathrm{C}$} & $1 \mathrm{~m}$ & 0.44 & Very Comfortable & $9.08 \%$ \\
\hline & & $1.5 \mathrm{~m}$ & 0.38 & Very Comfortable & $8.06 \%$ \\
\hline & \multirow{2}{*}{$18.5^{\circ} \mathrm{C}$} & $1 \mathrm{~m}$ & 0.59 & Comfortable & $12.25 \%$ \\
\hline & & $1.5 \mathrm{~m}$ & 0.48 & Very Comfortable & $9.9 \%$ \\
\hline & \multirow{2}{*}{$19.5^{\circ} \mathrm{C}$} & $1 \mathrm{~m}$ & 0.74 & Comfortable & $16.45 \%$ \\
\hline & & $1.5 \mathrm{~m}$ & 0.68 & Comfortable & $14.67 \%$ \\
\hline & \multirow{2}{*}{$20.5^{\circ} \mathrm{C}$} & $1 \mathrm{~m}$ & 0.89 & Slightly Warm & $21.9 \%$ \\
\hline & & $1.5 \mathrm{~m}$ & 0.86 & Slightly Warm & $20.7 \%$ \\
\hline \multirow[t]{8}{*}{ Surgeon assistants } & \multirow{2}{*}{$17.5^{\circ} \mathrm{C}$} & $1 \mathrm{~m}$ & 0.1 & Very Comfortable & $5.21 \%$ \\
\hline & & $1.5 \mathrm{~m}$ & 0.03 & Very Comfortable & $5.02 \%$ \\
\hline & \multirow{2}{*}{$18.5^{\circ} \mathrm{C}$} & $1 \mathrm{~m}$ & 0.24 & Very Comfortable & $6.23 \%$ \\
\hline & & $1.5 \mathrm{~m}$ & 0.15 & Very Comfortable & $5.48 \%$ \\
\hline & \multirow{2}{*}{$19.5^{\circ} \mathrm{C}$} & $1 \mathrm{~m}$ & 0.43 & Very Comfortable & $8.79 \%$ \\
\hline & & $1.5 \mathrm{~m}$ & 0.34 & Very Comfortable & $7.44 \%$ \\
\hline & \multirow{2}{*}{$20.5^{\circ} \mathrm{C}$} & $1 \mathrm{~m}$ & 0.59 & Comfortable & $12.33 \%$ \\
\hline & & $1.5 \mathrm{~m}$ & 0.56 & Comfortable & $11.65 \%$ \\
\hline \multirow[t]{8}{*}{ Anesthetists } & \multirow{2}{*}{$17.5^{\circ} \mathrm{C}$} & $1 \mathrm{~m}$ & -0.76 & Slightly Cool & $17.19 \%$ \\
\hline & & $1.5 \mathrm{~m}$ & -0.8 & Slightly Cool & $18.48 \%$ \\
\hline & \multirow{2}{*}{$18.5^{\circ} \mathrm{C}$} & $1 \mathrm{~m}$ & -0.58 & Comfortable & $12.12 \%$ \\
\hline & & $1.5 \mathrm{~m}$ & -0.65 & Comfortable & $13.93 \%$ \\
\hline & \multirow{2}{*}{$19.5^{\circ} \mathrm{C}$} & $1 \mathrm{~m}$ & -0.32 & Very Comfortable & $7.14 \%$ \\
\hline & & $1.5 \mathrm{~m}$ & -0.43 & Very Comfortable & $8.85 \%$ \\
\hline & \multirow{2}{*}{$20.5^{\circ} \mathrm{C}$} & $1 \mathrm{~m}$ & -0.11 & Very Comfortable & $5.23 \%$ \\
\hline & & $1.5 \mathrm{~m}$ & -0.05 & Very Comfortable & $5.05 \%$ \\
\hline
\end{tabular}

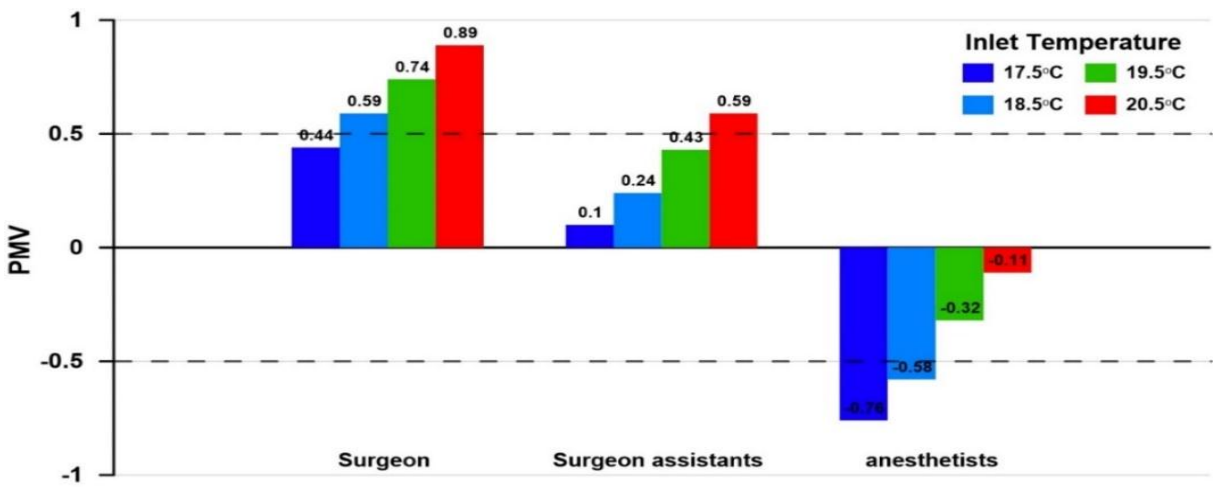

(a)

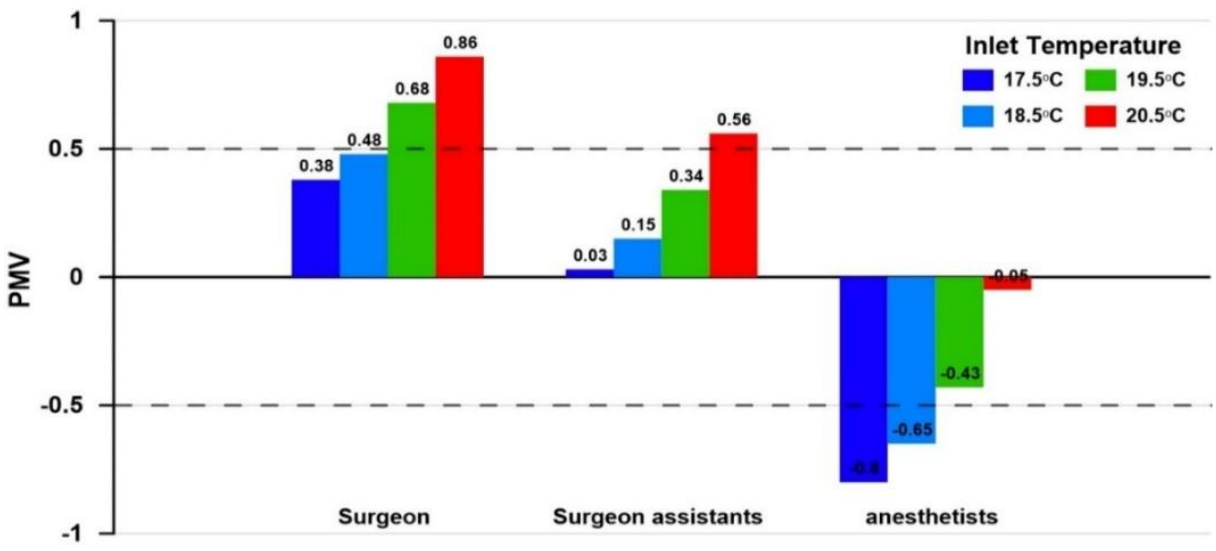

(b)

Fig. 11 PMV index for four cases at (a) $y=1 \mathrm{~m}$ and (b) $y=1.5 \mathrm{~m}$. 


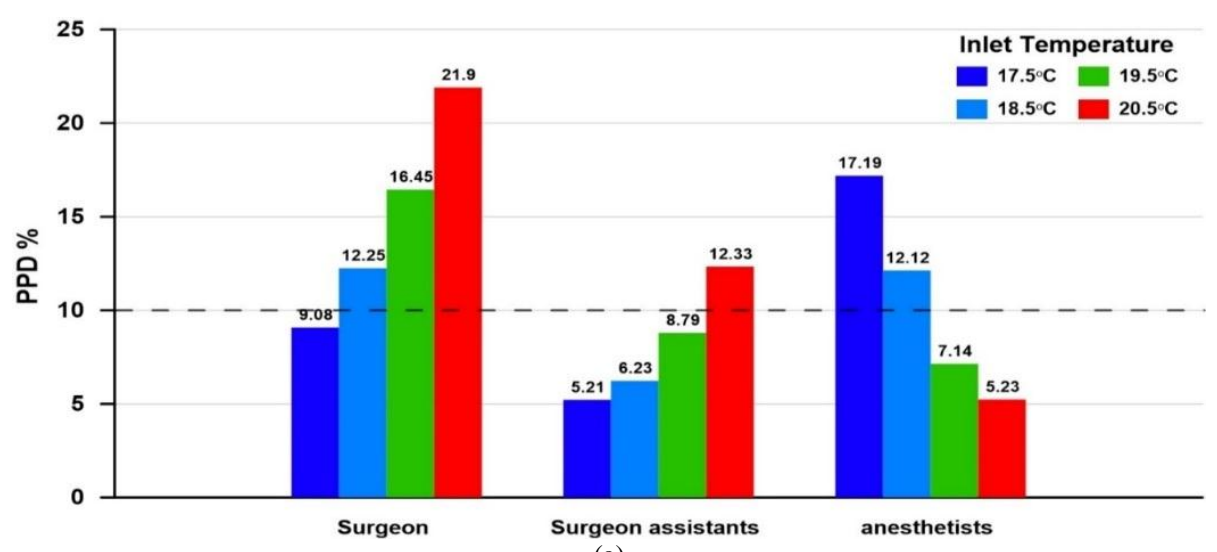

(a)

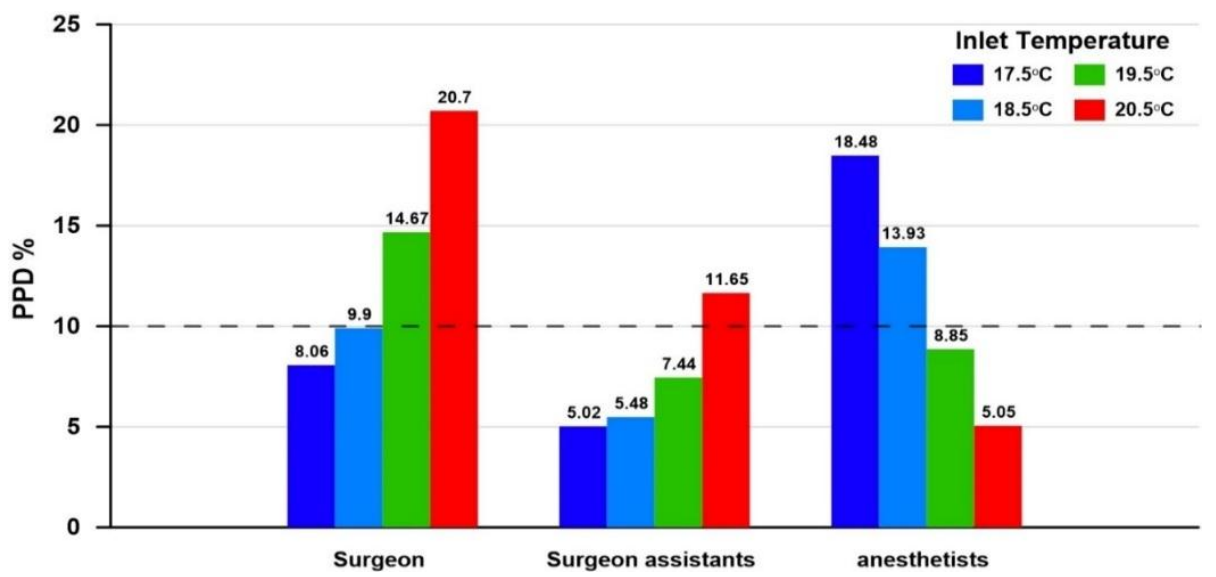

(b)

Fig. 12 PPD index for four cases at (a) $y=1 \mathrm{~m}$ and (b) $y=1.5 \mathrm{~m}$.

It can be observed from Fig. 11 that the group of surgeons $\left(120 \mathrm{~W} / \mathrm{m}^{2}\right)$ felt 'very comfortable' at inlet air temperature of $17.5^{\circ} \mathrm{C}$ and $18.5^{\circ} \mathrm{C}$ and 'comfortable' at $19.5^{\circ} \mathrm{C}$, but the thermal environment was 'slightly warm' at $20.5^{\circ} \mathrm{C}$. For the group of surgeons' assistants (100 $\mathrm{W} / \mathrm{m}^{2}$ ), conditions would be perceived as 'very comfortable' at $17.5^{\circ} \mathrm{C}, 18.5^{\circ} \mathrm{C}$ and $19.5^{\circ} \mathrm{C}$, but 'comfortable' at $20.5^{\circ} \mathrm{C}$ of supplied temperature. In case of anesthetists $\left(70 \mathrm{~W} / \mathrm{m}^{2}\right)$, they felt 'slightly cool' at $17.5^{\circ} \mathrm{C}$, 'comfortable', at $18.5^{\circ} \mathrm{C}$ and 'very comfortable' at $19.5^{\circ} \mathrm{C}$ and $20.5^{\circ} \mathrm{C}$.

\section{CONCLUSIONS}

In this study, thermal comfort of operating staff in an OR was investigated under the current ventilation system as indicated. PMV and PPD indices were used to evaluate the thermal conditions according to ISO 7730 which calculated based on data collected from field measurements. Four inlet air temperature cases were studied in order to evaluate the airflow patterns and surgical thermal comfort and find the optimal supplied air temperature. The main findings revealed that:

- The changes in inlet air temperatures have minor effect on the air velocities and airflow patterns inside the OR.
- It is difficult to create a comfortable work conditions for all operating staff due to their different thermal requirements.

- For the current ventilation system, supplied air temperature of $18.5^{\circ} \mathrm{C}$ provides almost comfortable conditions for all surgical staff.

- For surgeons, they felt 'very comfortable' at inlet air temperature of $17.5^{\circ} \mathrm{C}$ and it should not be higher than $18^{\circ} \mathrm{C}$.

- In case of surgeons' assistants, $17.5^{\circ} \mathrm{C}, 18.5^{\circ} \mathrm{C}$ and $19.5^{\circ} \mathrm{C}$ supplied air temperatures achieved a 'very comfortable' thermal environment in addition to that it should not go higher than $19.5^{\circ} \mathrm{C}$.

- The group of anesthetists felt 'very comfortable' at inlet air temperature of both $19.5^{\circ} \mathrm{C}$ and $20.5^{\circ} \mathrm{C}$ and it should not be below $19.5^{\circ} \mathrm{C}$.

In order to get a very comfortable thermal environment inside the operating room for all surgical staff, that could be achieved by controlling the thermal insulation of clothing for the same ventilation system and single specified inlet air temperature value or by providing differential supplied air temperatures. Those methods shall be examined in the future. 


\section{REFERENCES}

E. ISO, "14644-1,"Cleanrooms and associated controlled environments-Part 1: Classification of air cleanliness,"” European Standard, 1999.

[2] S. Dharan and D. Pittet, "Environmental controls in operating theatres," Journal of Hospital Infection, vol. 51, no. 2, pp. 79-84, 2002.

E. Marcon, S. d. Kharraja, and G. Simonnet, "The operating theatre planning by the follow-up of the risk of no realization," International Journal of Production Economics, vol. 85, no. 1, pp. 83-90, 2003.

[4] A. Macario, T. Vitez, B. Dunn, and T. McDonald, "Where are the costs in perioperative care?: Analysis of hospital costs and charges for inpatient surgical care," Anesthesiology: The Journal of the American Society of Anesthesiologists, vol. 83, no. 6, pp. 11381144, 1995.

[5] W. A. C. Zoon, M. G. M. Heijden, M. G. L. C. Loomans, and J. Hensen, "On the applicability of the laminar flow index when selecting surgical lighting," Building and Environment, vol. 45, pp. 1976-1983, 09/01 2010.

[6] F. Memarzadeh, "Reducing Risk of Surgery," ASHRAE Journal, vol. 45, 02/01 2003.

[7] C. Balaras, E. Dascalaki, and A. Gaglia, "HVAC and indoo thermal conditions in hospital operating rooms," Energy and Buildings, vol. 39, pp. 454-470, 04/01 2007.

[8] J. Verheyen, N. Theys, L. Allonsius, and F. Descamps, "Thermal comfort of patients: Objective and subjective measurements in patient rooms of a Belgian healthcare facility," Building and Environment, vol. 46, no. 5, pp. 1195-1204, 2011/05/01/ 2011.

[9] A. S. o. Heating, Refrigerating, A.-C. Engineers, and A. N. S Institute, Thermal environmental conditions for human occupancy (no. 2004). American Society of Heating, Refrigerating and AirConditioning Engineers, 2004.

[10] P. O. Fanger, "Assessment of man's thermal comfort in practice," British Journal of Industrial Medicine, vol. 30, no. 4, p. 313, 1973

[11] D. Leeth, M. Mamaril, K. S. Oman, and B. Krumbach, "Normothermia and Patient Comfort: A Comparative Study in an Outpatient Surgery Setting," Journal of PeriAnesthesia Nursing, vol. 25 , no. 3, pp. 146-151, 2010

[12] S. Mazzacane, C. Giaconia, S. Costanzo, and G. Lupo, "On the Assessment of the Environmental Comfort in Operating Theatres," 01/01 2006

[13] K. Leslie and D. I. Sessler, "Perioperative hypothermia in the highrisk surgical patient," Best Practice \& Research Clinical Anaesthesiology, vol. 17, no. 4, pp. 485-498, 2003/12/01/ 2003.

[14] W. C. Beck, N. L. Belkin, and K. K. Meyer, "Divide and Conquer-Protection, Comfort, and Cost of the Surgeon's Gown," The American Journal of Surgery, vol. 169, no. 3, pp. 286-287, 1995.

[15] M. Melhado, J. Hensen, and M. G. L. C. Loomans, "Literature Review of Staff Thermal Comfort and Patient "Thermal Risks" in Operating Rooms," Automation in Construction - AUTOM CONSTR, 01/01 2006.

[16] J. Khodakarami and N. Nasrollahi, "Thermal comfort in hospitals - A literature review," Renewable and Sustainable Energy Reviews, vol. 16, pp. 4071-4077, 08/01 2012.

[17] A. Pourshaghaghy and M. Omidvari, "Examination of thermal comfort in a hospital using PMV-PPD model," Applied Ergonomics, vol. 43, no. 6, pp. 1089-1095, 2012/11/01/2012.

[18] E. Dascalaki, A. Gaglia, C. Balaras, and A. Lagoudi, "Indoor environmental quality in Hellenic hospital operating rooms," Energy and Buildings, pp. 551-560, 01/25 2009.

[19] R. Berg et al., "The impact of heat stress on performance and cognitive function during simulated laparoscopic surgical tasks," Surgery, vol. 157, pp. 87-95, 01/31 2015.

[20] G. Abbritti et al., "High Prevalence of Sick Building Syndrome in a New Air-Conditioned Building in Italy," Archives of Environmental Health: An International Journal, vol. 47, no. 1, pp. 16-22, 1992/02/01 1992.

[21] R. Van Gaever, V. A. Jacobs, M. Diltoer, L. Peeters, and S. Vanlanduit, "Thermal comfort of the surgical staff in the operating room," Building and Environment, vol. 81, pp. 37-41, 2014/11/01/ 2014.

[22] P. Uścinowicz, A. Bogdan, and M. Chludzinska, "Thermal comfort in hospital operating rooms within legislative and normative documents," Dist. Heat. Heat. Vent., vol. 45, 01/01 2014.
[23] S. Mazzacane, C. Giaconia, S. Costanzo, and A. Cusumano, "A Survey on the Thermal Conditions Experienced by a Surgical Team," Indoor and Built Environment - INDOOR BUILT ENVIRON, vol. 16, pp. 99-109, 04/01 2007.

[24] R.-L. Hwang, M.-J. Cheng, T.-P. Lin, and M.-C. Ho, "Thermal perceptions, general adaptation methods and occupant's idea about the trade-off between thermal comfort and energy saving in hothumid regions," Building and Environment, vol. 44, no. 6, pp. 1128-1134, 2009/06/01/2009.

[25] S. H. Ho, L. Rosario, and M. M. Rahman, "Thermal comfort enhancement by using a ceiling fan," Applied Thermal Engineering vol. 29, no. 8, pp. 1648-1656, 2009/06/01/2009

[26] W. Khalid, S. A. Zaki, H. B. Rijal, and F. Yakub, "Investigation of comfort temperature and thermal adaptation for patients and visitors in Malaysian hospitals," Energy and Buildings, vol. 183, pp. 484-499, 2019/01/15/2019.

[27] G. Cook and D. Int-Hout, "Air motion control in the hospital operating room," Ashrae Journal, vol. 51, no. 3, p. 30, 2009.

[28] F. Memarzadeh and A. P. Manning, "Comparison of operating room ventilation systems in the protection of the surgical site/Discussion," ASHRAE transactions, vol. 108, p. 3, 2002.

[29] N. El Gharbi, A. Benzaoui, E. E. Khalil, and R. Kameel, "Analysis of indoor air quality in surgical operating rooms using experimental and numerical investigations," Mechanics \& Industry, vol. 13 , no. 2, pp. 123-126, 2012.

[30] E. ISO, "7730," Ergonomics of the thermal environmentanalytical determination and interpretation of thermal comfort using calculation of the PMV and PPD indices and local thermal comfort criteria, Standards Norway, Oslo, Norway, 2005.

[31] A. Standard, "Standard 55-2013 Thermal environmental conditions for human occupancy," ASHRAE, Atlanta, GA, vol. 30329, 2013.

[32] P. Fanger, "Thermal Comfort, Danish Technical Press," Copenhagen, Denmark, 1970.

[33] S. Zhang, W. He, D. Chen, J. Chu, H. Fan, and X. Duan, "Thermal comfort analysis based on PMV/PPD in cabins of manned submersibles," Building and Environment, vol. 148, pp. 668-676, 2019/01/15/2019.

[34] X. U. Junzeng, W. E. I. Qi, P. Shizhang, and Y. U. Yanmei, "Error of Saturation Vapor Pressure Calculated by Different Formulas and Its Effect on Calculation of Reference Evapotranspiration in High Latitude Cold Region," Procedia Engineering, vol. 28, pp. 43-48, 2012/01/01/ 2012.

[35] M. Zwolińska and A. Bogdan, "Thermal Sensations of Surgeons During Work in Surgical Gowns," International Journal of Occupational Safety and Ergonomics, vol. 19, no. 3, pp. 443-453, 2013/01/01 2013

[36] A. Bogdan, I. Sudoł-Szopińska, and T. Szopiński, "Assessment of textiles for use in operating theatres with respect to the thermal comfort of surgeons," Fibres \& Textiles in Eastern Europe, vol. 19, no. 2 , pp. 65-9, 2011.

[37] Z. Rui, T. Guangbei, and L. Jihong, "Study on biological contaminant control strategies under different ventilation models in hospital operating room," Building and Environment, vol. 43, no. 5, pp. 793-803, 2008/05/01/2008. 